Canadian University Music Review

Revue de musique des universités canadiennes

\title{
Táncház in Toronto: A Transplanted Tradition
}

\section{Stephen Satory}

Numéro 8, 1987

URI : https://id.erudit.org/iderudit/1014933ar

DOI : https://doi.org/10.7202/1014933ar

Aller au sommaire du numéro

Éditeur(s)

Canadian University Music Society / Société de musique des universités

canadiennes

ISSN

0710-0353 (imprimé)

2291-2436 (numérique)

Découvrir la revue

Citer cet article

Satory, S. (1987). Táncház in Toronto: A Transplanted Tradition. Canadian University Music Review / Revue de musique des universités canadiennes, (8), 45-61. https://doi.org/10.7202/1014933ar

All Rights Reserved (C Canadian University Music Society / Société de musique des universités canadiennes, 1986
Ce document est protégé par la loi sur le droit d'auteur. L'utilisation des services d'Érudit (y compris la reproduction) est assujettie à sa politique d'utilisation que vous pouvez consulter en ligne.

https://apropos.erudit.org/fr/usagers/politique-dutilisation/ 


\section{TÁNCHÁZ IN TORONTO: A TRANSPLANTED TRADITION}

\section{Stephen Satory}

In his book, The Interpretation of Culture, Clifford Geertz propounded a concept of culture that is "not an experimental science in search of law but an interpretive one in search of meaning" (1973: 5). Such meanings are sought in the historical developments, social forms, and individual contributions which all contribute to culture. ${ }^{1}$ Paraphrasing Geertz, Tim Rice has argued that "music is historically constructed, socially maintained and individually adapted."2 I will use this model to discuss the dynamics of folk music and of folk dance in Toronto's Hungarian community where I conducted field research from November, 1984 to March, 1985. Rather than dealing with Hungarian folk music in general, I will focus on its most recent importation to Toronto, the so-called Táncház (or "dance-house") tradition of improvised dancing and Gypsy-style string band music.

By way of introduction, it is important to describe a Táncház event, the roles of the dancers and musicians and the extent to which they improvise within the Táncház tradition. According to informant Árpád

1 See Clifford Geertz, The Interpretation of Culture, (New York: Basic Books, 1973), p. 52: "Becoming human is becoming individual, and we become individual under the guidance of cultural patterns, historically created systems of meaning in terms of which we give form, order, point, and direction to our lives. And the cultural patterns involved are not general but specific ..." See also p. 145: "Culture is the fabric of meaning in terms of which human beings interpret their experience and guide their action; social structure is the form that action takes, the actually existing network of social relations."

2 Professor Rice's paraphrase was first given on February 20, 1985, in the Graduate Ethnomusicology Seminar, Faculty of Music, University of Toronto. The model was subsequently published in Ethnomusicology 31(3): 469-88, 1987. 
Verseghy, violinist and leader of a Gypsy-style string band in Toronto, there are two kinds of Táncház, the teaching Táncház and the "goodtime" Táncház. ${ }^{3} \mathrm{~A}$ Táncház atmosphere is quite unlike the atmosphere of a rehearsal of choreographed dancing. It is free and easy; there are no obligations. "Even with a teaching Táncház, anyone can walk out and leave. A good-time Táncház is absolutely a free-for-all, a party situation. You just play and dance and that's it."4

Informant George Tömössy, a dancer with Toronto's Kodály Dance Ensemble, described the dancer's task in a Táncház setting: "You're given a motif which fits a certain rhythm in the dance and you have to become accustomed to spotting certain rhythms and sequences of rhythms and applying certain combinations of steps, and that can only be done through practice and listening to the music."5 Thus the freedom of the dancer's improvisation is limited in two ways: specific musical melodies and rhythms give rise to related, similarly specific dance steps, and, in a broader sense, the choice of steps by which the dancers respond to the music is limited by the style boundaries of the locality from which the dance and musical dialect spring. ${ }^{6}$

3 Interview with Verseghy on February 20, 1985.

4 Ibid. Later, Verseghy clarified the relationship between the two kinds of Táncház: "It's nice to have a visiting choreographer for a whole day. Then you can have a three- or four-hour teaching session in the late morning or early afternoon, then adjourn for food and drink and whatnot, and then have a party Táncház at night at which the band will then play music from the region which was taught in the afternoon."

5 Interview with Tömössy, February 26, 1985.

6 In Táncház dancing as in choreographed stage dancing, men's dances are invariably more complex, more difficult and a great deal more showy, more spectacular than women's dances. Thus, the limits for improvisation in Táncház are far broader for men than for women. See György Martin, ed. Magyar Néptánchagyományok [Hungarian folk dance traditions], Budapest: Zenemukiadó, 1980, pp. 11-15. 
The string bands generally consist of three to five players, one or two prímás-es or violins, one or two brácsa (viola) players and a bögö (string bass, or at times, violoncello) player. These string players improvise as well in a Táncház setting. The violinists' ornamentation and the varying stress patterns of the viola and bass players is limited by two factors: the stylistic boundaries of the village dialects from which the music emanates, and by the needs of the dancers. To render the music clearer and more easily danceable, violinists use ornamentation to emphasize strong beats; stress patterns in brácsa and bögö playing serve similar ends. ${ }^{7}$

Let us now return to the historical construction of Toronto's Hungarian traditions, which occurred through three periods of immigration. The first of these periods was through the 1920s and 1930s, the second in the years immediately after the Second World War, and the third, after the Revolution of $1956 . .^{8}$ It is the wave of immigration of 1956 which

7 Árpád Verseghy has reported that in the Hungarian communities of Transylvania of long ago, the Gypsy prímás played solo at village dance occasions; the brácsa and bögö were added only in the late nineteenth century (Interview, February 20,1985). The prímás had the responsibility of rounding up band members at harvest time for the entertainment events of the fall and winter season. Larger bands of approximately eight members were hired for more important social occasions, when more money was available to pay for the services of the musicians. The additional instruments often included a second prímás, a clarinet and a cimbalom and both the kisbögö (small bögö or violoncello) and the nagybögö (large bögö or bass) were present. See Lászlo Lajtha, Körispataki Gyüjtés [Körispatak collection], (Zenemükiadó, Budapest, 1955), p. 9. Regarded as a professional musician by the villagers, the Gypsy primás was able to play the brácsa and bögö as well, and often demonstrated harmonies and bowing techniques to brácsa and bögö players. He always started the tunes and the others of the band followed suit and began to play only after they recognized the tune. According to Lajtha, "these bands retain the improvisatory essence of folk art." (Loc.cit.) That is, the prímás was at liberty to improvise on the tune, and the brácsa and bögö players could also add notes and change rhythms, in improvisatory fashion. See Lajtha's transcriptions in the cited work and in Széki Gyüjtés (Zenemükiadó, Budapest, 1954).

8 See Susan M. Papp-Zubrits, "Reflections of the members of three waves of 
led to a proliferation of cultural and musical organizations in Toronto. 9

Several organizations related to folk culture are housed in the Hungarian Canadian Cultural Centre, founded in 1974. The Kodály Dance Ensemble rehearses there weekly and has a total membership of 50 to 60 dancers. Another large performing group is the Kodály Chorus, with about 45 adult voices. Both of these groups were founded in 1963. In addition a citera (zither) orchestra, called the Szivárvány Együttes (Rainbow Ensemble) was begun in 1982 by István Erdélyi.

Further, there are two string bands which rehearse in the basement recreation rooms of various members. One group, Életfa (Tree of Life) was begun two years ago as the "house band" of the Kodály Dance Ensemble, and is comprised of three, sometimes four players: it has one prímás, one or two brácsa players and a bögö player. A similar group is Feketeföld (Black Earth) which has operated independently for nine years and has two prímás-es.

The Táncház movement was initiated in Hungary by the urban musicians, Béla Halmos and Ferenc Sebö; as a result of their folk music collecting trips among Hungarians in Transylvania, now a part of Roumania, they managed to smuggle across the border field recordings from various villages. This village tradition of dance and music very quickly became an extremely popular means of participatory entertainment and socialization in the Táncház clubs of Budapest.

Táncház was eventually transmitted to Toronto in the following ways: firstly, young dancers and musicians from Toronto have visited Hungary to attend workshops and seminars in Táncház dancing and

Hungarian immigrants in Ontario," in Roots and Realities among Eastern and Central Europeans (Central and East European Studies Association of Canada, Edmonton, 1983), pp. 155-164.

9 See George Bisztray, "Why 1956? Recent cultural changes in the Hungarian community", in ibid. pp. 165-171. See also George Zadubán, "Hungary" in Helmuth Kallmann, et al., eds. Encyclopedia of Music in Canada Toronto: University of Toronto Press, 1981, p. 439. 
string playing; 10 moreover, they have brought back to Toronto taped field recordings as well as many folk instruments and costumes. Secondly, several Hungarian experts have visited Toronto to give courses and seminars in dancing and instrumental playing. ${ }^{11}$ Thirdly, young Hungarians have encountered Hungarian and Transylvanian village music by finding recordings in libraries and in record shops. ${ }^{12}$ Fourthly, Béla Halmos' transcriptions of dance tunes containing skeletal melodies and conventional chord symbols have been brought from Hungary and have been used consistently at the rehearsals of the string bands in Toronto. And lastly, copies are available of the well-known, fully detailed, phonetic transcriptions of two village repertories of Transylvania, which were published in 1954 and 1955 in Budapest by the ethnomusicologist, László Lajtha. ${ }^{13}$

Knowledge of Hungarian culture can be obtained in the new urban environment of Toronto through various Hungarian organizations and institutions like the Hungarian scouting movement, various youth clubs and the Saturday school taught at the Cultural Centre. It is interesting to note that Hungarian culture is available at non-Hungarian insti-

10 Interview with Mária Kovács (pseudnym) on February 15, 1985, with Gábor Vaski on February 7, 1985 and Kálmán Dreisziger on December 30, 1985 and February 15, 1985.

11 A number of dance teachers have come to Toronto from Hungary, as well as Béla Halmos, the "foremost teacher of Transylvanian violin playing," (Árpád Verseghy, February 20, 1985) and Mátyás Pribojszki, the greatest Hungarian citera player of our day.

12 It was the discovery in 1975 of a record album of Hungarian folk music published by UNESCO at the Toronto Public Music Library that first awakened the interest of Árpád Verseghy in village music making and led to informal music-making sessions thereafter with friends, and eventually to Gypsy-style string band playing. Initially, Verseghy's band was named Mezöségi Banda (Mezöség Band, Mezöség being a region of central Transylvania); subsequently, the name of the band was changed to Feketeföld.

13 See Lajtha's introductions to Széki Gyüjtés (1954) and Körispataki Gyüjtés (1955). 
tutions as well, in public libraries, in high school courses and from the recently founded Chair of Hungarian Studies at the University of Toronto.

The ways in which this music and dancing are socially maintained are highlighted by the comparison of the three venues in which Táncház music and dance are preserved. In the Hungarian villages of Transylvania, Táncház activity took the form of Friday evening gettogethers in community halls, in barns, in villagers' living rooms. There, the dancing, accompanied by Gypsy string music, functioned as entertainment for villagers of all ages, providing dancers with opportunities for impromptu socializing and furnishing gainful employment for the string band members, particularly for the Gypsy primás. ${ }^{14}$ In Hungary, a strong tradition of choreographed, staged folk dancing has been maintained, with government support, since the 1950s. Beginning in 1971, however, Táncház clubs were founded in Budapest and in other Hungarian cities to provide teaching sessions for young people to learn to improvise using village dance dialects. ${ }^{15}$ In addition, recreational Táncház-es have successfully transplanted village music and dancing unto city soil, so affording city people, particularly young people, occasions for entertainment and socializing in the improvisatory spirit of the villages. Today in Budapest, Táncház sessions continue to be offered every day of the week. ${ }^{16}$

See Lajtha, Körispataki Gyüjtés (1955), p. 9.

15

See János Szász, "Beszélgetés Martin Györggyel az új folklórhullám és néptáncmozgalom elözményeiröl" (Conversation with György Martin concerning the sources of the new folklore and folkdance movement) in Kultúra es Közösség (Culture and community), Budapest, IV, 1981, pp. 42-53.

According to Árpád Verseghy, there has been a particular upsurge in the number of string bands, which compete to accompany folk dance groups (Interview on March 14, 1985). Consistent with their origins in rock and roll music, Táncház bands like Muzsikás have introduced "western" influences where blues numbers with harmonica and electric bass alternate with the village dance pieces. In addition, Táncház-es have recently incorporated South Slav dance-house styles (which are "easier to perform" than 
The reasons for the continuing popularity of the Táncház movement in Hungary in the last fourteen years are twofold: firstly, Hungarians need to make a palpable connection with the stranded, isolated Hungarian community of Transylvania; with the gradual easing in recent years of political tensions in Hungary, there has been growing concern in Hungary and in Canada as well for the welfare of the oppressed Hungarians of Transylvania and a renewed interest in Transylvanian village life. ${ }^{17}$ Secondly, in the continuing urban youth scene of Budapest, the Táncház clubs are the descendants of the ballroom dance schools of the 1920s and 1930s and of the rock clubs of the 1960s and 1970s. In short, the young people of Budapest and of other Hungarian cities have frequented dance clubs for generations.

In Toronto, it is the choreographed dancing that has been very successful. ${ }^{18}$ Neither the folk dancers nor the Hungarian community have shown great interest in the Táncház movement. Why has the movement not been more popular in Toronto? The reason lies in the lack of compatibility between Táncház and the values espoused by the

Transylvanian dialects) and Gypsy dances (Interview with Árpád Verseghy, February 20, 1985).

17 For accounts of the political, economic and cultural oppression of the Hungarians in Transylvania, see Napocensis, Anonymus, "Methods of Rumanianization employed in Transylvania," in Witnesses to Cultural Genocide (ed. by G. Schöpflin, American Transylvanian Federation and Committee for Human Rights in Roumania, New York, 1979), pp. 57-87; Kúnszabó, Ferenc, "Modernized genocide" in Transylvania and the Hungarian Roumanian Problem (edited by A.F. Sanborn and G.W. de Czege, Danubian Press, Astor, Florida, 1979), pp. 261-71; Veress, Bulcsú, "The status of minority rights in Transylvania, international legal expectations and Roumanian realities" in Transylvania: the Roots of Ethnic Conflict (edited by J.F. Caldow, A. Ludányi and L. J. Elteto, Kent State University Press, Kent, Ohio, 1983), pp.269-88; see also Verdery, Katherine, Transylvanian Villagers (University of California Press, Berkeley, 1983).

18 Interviews with Kálmán Dreisziger (February 15, 1985, and December 30, 1984), Árpád Verseghy (December 19, 1984 and February 20, 1985), Mária Kovács (February 15, 1985) and Gábor Vaski (February 7, 1985). 
Hungarian community, which are, in the words of one of my informants, "goal orientation and hard work."19

Goal orientation is not present in Táncház beyond the learning of dance dialects for their own sake; it is improvisational, experimental, with no performing occasion in mind. Conversely, choreographed dancing does provide the goal for young dancers of gaining the approval of their parents and of the community.

Most Hungarian folk dancers of Toronto see Táncház dancing not as hard work but as an "unstructured activity". In it, there is no regimentation, no obligation, no commitment to stay. It has been described as a "free-for-all", with lots of smoking, drinking, and telling of jokes - in short, a party situation. ${ }^{20}$ All of these characteristics oppose the ethic of hard work that the immigrant Hungarian community is committed to fostering.

Moreover, in being an art that is tied to the dialects of specific villages, Táncház lacks the Hungarian-ness of many choreographed dances; consequently, it also lacks the approbation that choreographed dance performances receive at patriotic ceremonies like the commemorations of the Revolutions of 1848 and 1956.

And lastly, choreographed dancing is preferred to Táncház because of the community's interest in promulgating a concert tradition; most Hungarians of Toronto do not participate in folk dancing and are certainly not interested in learning about difficult Táncház dance dialects from remote Transylvanian villages. But they are a willing and supportive audience for choreographed, presentational dancing. ${ }^{21}$

Clearly then, the Táncház tradition, with its improvisational and recreational nature, has not "caught on" in Toronto on a community-wide

19 Interview with Gábor Vaski on February 7, 1985.

20 Interview with Árpád Verseghy, February 20, 1985.

21 Interview with Mária Kovács on February 15, 1985. 
basis. It can, however, be said to serve the needs of at least a small number of individuals who come to it with a variety of unique backgrounds, unique even if they are united by their membership in the Hungarian-Canadian community. These several individuals have consistently dedicated their time to playing and dancing in the Táncház tradition, and have adapted Táncház individually in a number of ways. Moreover, they continue to feel the responsibility for transmitting Táncház to the Hungarian community. ${ }^{22}$

Of the five informants that were interviewed, two were musicians, two were dancers and one, a musician-dancer. This last is Gábor Vaski, twenty-two years old. Gábor's parents live in Kelowna, British Columbia where he attended primary and secondary school. He started Hungarian dancing at the age of eight, began playing saxophone at the age of eleven and has studied classical music since that time. Formerly a student at Humber College, Toronto, he currently studies music and Hungarian at the University of Toronto. Between 1981 and 1984, he was a member of the Kodály Dance Ensemble. He is also the new bögö player in the Életfa string band.

Involvement in Hungarian folk art and in Táncház has served as a means of retaining and reinforcing ethnic identity for Vaski. He expresses his Hungarianness through dancing, playing bögö and by studying Hungarian language and literature. $\mathrm{He}$ said in an interview: "...being Hungarian is extremely important to me, second only to my ambition to become a successful musician."23 Vaski has enjoyed participating in Táncház but has been daunted somewhat by the difficulty of Táncház dancing. He observed that Táncház has had only limited success in Toronto. In his view, there are not enough Táncház dancers or musicians in any North American community to spark sufficient interest.

22 Kálmán Dreisziger, “Magyar Néptánccsoportok felelössége," (The responsibility of Hungarian folk dance groups) in Magyar Népmüvészet Kanadában (Hungarian Folk Art in Canada), I(1), December 1983.

23 Interview on February 7, 1985. 
Árpád Verseghy is thirty-four years old and was born in Regau, Austria, in a camp for Hungarian immigrants. His family arrived in Canada in 1954 and settled in Toronto. Verseghy began to study violin at the age of seven, attended primary and secondary school in Toronto and studied music at Queen's University in Kingston and at the University of Toronto. He has taught string music at Runnymede Collegiate in Toronto for the last ten years.

Inspired by his encounter with the Táncház revival in 1975 (see footnote ten) Verseghy quickly managed to secure taped recordings of two of the best-known early Táncház groups, Sebö Együttes and Muzsikás. Verseghy's musical group began not as a performing group but as a meeting of musical friends in a bungalow basement for "music-making, wine-drinking, smoking, joke-telling and what-not, just to amuse ourselves." 24 Nevertheless, the group, called the Mezöségi Banda, was soon involved in performing in a concert setting. Owing to its expanding repertoire and its departure from the music of Mezöség, the group's name was changed in 1976 to Feketeföld.

For three seasons, from 1980 to 1983, the Feketeföld band had its own dancers; there were, on the average, five couples. Remarkably, in a Feketeföld Ensemble Concert in 1982 at the Concert Hall of the Royal Conservatory, Toronto, close to half of the dancing was improvised. "Then we experimented with things like coming back into a choreographed thing, to whip up a finale, you know. You can whip up a little more steam when everybody's doing the same thing."2s But, due to the "extremely chaotic appearance of the staged Táncház"26 subsequent Feketefölf Ensemble concerts presented only choreographed dancing. Thus, in Verseghy's own experience, the transplanting of Táncház from a teaching and party context into a concert setting proved unsuccessful.

24 Interview on February 20, 1985.

25 Ibid.

26

Ibid. 
Despite his own enthusiasm for and devotion to Táncház, Verseghy's attitude is one of discouragement regarding its survival in Toronto. In his view, improvisatory dancing is possible only after protracted specialization and in-depth familiarity with a given village dialect: "Since people here in Toronto are not village members, it's almost impossible to expect that they become thoroughly engrossed in any one dance culture."27

Nonetheless, Verseghy ardently identifies himself as a Hungarian and for him Táncház is an all-consuming hobby. He has a vast collection of Táncház field recordings and makes his own folk instruments, the most recent of which is an authentic cimbalom.

Verseghy's co-prímás with Feketeföld and the prímás of the Életfa band is Mária Kovács (pseudonym), born in Toronto. She studied violin privately from the age of seven and played for three years in the Toronto Symphony Youth Orchestra. After coming into contact with Transylvanian village dance music in 1982, she became captivated by it and has played as a prímás since that time, but she has not returned to play the classical repertoire. Kovács likes the "teamwork aspect" of playing music together with others and she enjoys meeting the people who play together with her in the bands. She believes in actively retaining folklore as authentically as possible and feels that "it's nice to see people pick up a folk instrument and play it."28 Kovács involvement with Hungarian folk music thus stems from her liking for the music and for the social contacts that is afforded, but, unlike Vaski's and Verseghy's, her involvement is not clearly connected to a need for a Hungarian identity, for a powerful self-identification as a Hungarian.

Kálmán Dreisziger was born in Csorna, Hungary in 1945. His family immigrated to Canada in 1957 and lived in Welland, Ontario until 1960. Dreisziger attended high school and university in Toronto and joined the Kodály Együttes as a dancer in 1964; he became its leader

Ibid.

Interview on Febrary 15, 1985. 
in the late 1970s. Currently he works at an advertising agency in Toronto.

For Dreisziger, an effective way to reinforce Hungarian identity, which to him is extremely important, is to look to the past: "To empathize with the past is an incredibly positive force."29 Early in his childhood, he developed a powerful need to identify with Hungarian history and heritage. For him, Táncház provides "a close, real, intimate link with the past; it allows you to develop a bonding, which you can apply to real, as opposed to symbolic, situations." 30 The reality entails Dreisziger's continuing effort to preserve and promulgate the Táncház tradition in Toronto. The symbolism requires a magical, nostalgic voyage, a travel through time: “...there is a need for Canadian dancers to make a link with the Transylvanian dance culture, so that, if they should go to Transylvania, they would fit right in. They could enter into the ancient community and make music with its members." 31 Thus, the improvisatory dancing and music-making of Táncház has been adapted by Dreisziger as the means by which he and others might reach their historical and geographical ethnic roots in the Hungarian community of Transylvania.

George Tömössy was born in Toronto in 1969. He has studied piano for eight years and has played clarinet and saxophone in his high school band. Also interested in studying voice, he has five regular piano students and is considering pursuing music as a career. He is in his third season as a member of the Kodaly Dance Ensemble.

29 See Ellen Koskoff, "Contemporary Nigun Composition in an American Hasidic Community," in Selected Reports in Ethnomusicology III(1) (University of California, Los Angeles, 1978), pp. 153-173. Koskoff discusses the need of Nigun composers in the United States to look to the past for spiritual and musical models and inspiration (pp. 159-160).

See Kálmán Dreisziger, Op cit., pp. 2-3.

31

Ibid. 
In my interview with Tömössy, I asked him the question: "What has attracted you to folk dancing?" To this Tömössy replied:

The social factor is very important. It was a major appeal in my opinion. You can get social contact in many other ways, but the fact that I could combine social contact with my true Hungarian culture is very appealing. It provides good relaxation for me when I'm out of here and physically it helps me to stay in a little bit better shape. The fact that I have to sweat every Tuesday helps me to keep in trim, and also it's very enjoyable, that's what I mainly get out of it. The fact that I'm with other people, the fact that we're dancing, we're making an effort to achieve something ... it gives me a good feeling... I intend to continue dancing as long as I'm able to walk.

[Interview on Febuary 26, 1985].

Tömössy was extremely enthusiastic about dancing in Táncház situations; Relishing its challenge, he would like the Kodály Dance Ensemble to have Táncház sessions more regularly. He said, "We're trying to get people to adapt to more Táncház situations." 32

For Dreisziger and Tömössy and for other Hungarian folk dancers, Táncház affords the enjoyment of their own virtuosity and improvisational prowess. The difficulty of the steps and the concentration that is needed to do various dance steps to appropriate musical cues provide a physical, intellectual and artistic challenge.

In conclusion, Táncház has provided a focus of interest for young and energetic individual artists in the Hungarian community. These individuals have hoped to replicate the resounding success of the Táncház movement in Hungary. However, most dancers, and the community as a whole have resisted the advance of this unique improvisational art, preferring to stay with prerehearsed choreographed performances. The Hungarian community's preference for choreographed, presentational dancing can thus be understood in terms of its need to have a finished product, a demonstration of achievement at hand.

32 Ibid. 
Hungarian culture is available in Toronto in Hungarian institutions like dance ensembles and string bands as well as in non-Hungarian institutions like libraries, high schools and universities. In Hungary, Táncház has been steadily maintained alongside choreographed dancing, but in Toronto most of this support has gone to choreographed dancing. And finally, despite the fact that the Táncház tradition involves only a small part of the Hungarian community in Toronto, it does remain a very rich source of culture for certain dedicated individuals. 


\section{REFERENCES}

\section{BARTH, FREDRIK.}

1969: Ethnic Groups and Boundaries: the Social Organization of Culture Difference Boston: Little and Brown.

BISZTRAY, GEORGE.

1983: "Why 1956? Recent cultural changes in the Hungarian community.", in Roots and Realities among Eastern and Central Europeans, ed. by Martin L. Kovács, Edmonton: Central and Eastern European Studies Association of Canada, pp. 165-71.

DEGH, LINDA.

1968-69: "Survival and revival of European folk cultures in America", in Ethnologia Europea, Vol II-III, pp. 197-101.

1969: Folktales and Society: Storytelling in a Hungarian Peasant Community, Bloomington: Indiana University Press.

1971: Prepared comments to R.M. Dorson's "Is there a folk in the city?", in The Urban Experience and Folk Tradition, ed. by A. Paredes and E.J. Stewart, Austin: University of Texas, pp. 53-58.

1975: People in the Tobacco Belt: Four Lives Ottawa: National Museums.

\section{DREISZIGER, KÁLMÁN.}

1983: "Magyar néptánccsoportok felelössége" [The responsibility of Hungarian folk dance groups] in Magyar Népmüvészet Kanadában [Hungarian Folk Art in Canada], 1(1): 2-3.

\section{ERDELY, STEPHEN.}

1964: "Folksinging of the American Hungarians in Cleveland", in Ethnomusicology 8( ): 14-27.

1978: "Traditional and individual traits in the songs of three Hungarian Americans," in Selected Reports in Ethnomusicology, 3(1): 98-151, ed. by James Porter, Los Angeles: University of California.

\section{GEERTZ, CLIFFORD.}

1973: The Interpretation of Cultures, New York: Basic Books.

HALMOS, BELA.

1981: "Közjátékok egy széki vonósbanda tánczenéjében," [Ornamentation in the dance music of a string band from Szék] in Zenetudományi Tanulmányok [Studies in Musicology], Budapest, pp. 191-219.

HAMRÁN, ZSUZSA.

1983: "Válságban a Táncház-mozgalom?" [Is the Táncház movement in a struggle to survive?] in Magyar Népmüvészet Kanadában [Hungarian Folk Art in Canada] 1(1): 8. 
ISAJIW, WSEVOLOD.

1981: Ethnic Identity Retention, Toronto: Centre for Urban and Community Studies, University of Toronto.

KOSKOFF, ELLEN.

"Contemporary Nigun Composition in an American Hasidic Community", in Selected Reports in Ethnomusicology Los Angeles, University of California, 3(1): 153-73.

KÚNSZABÓ, FERENC.

1979: "Modernized Genocide", in Transylvania and the Hungarian-Roumanian Problem: a Symposium, ed. by A.F. Sanborn and G.W. de Czége, Astor, Florida: Danubian Press, pp. 261-71.

LAJTHA, LÁSZLÓ.

1953: "Egy 'hamis' zenekar" [An out-of-tune orchestra] in Emlékkönyv Kodály Zoltán 70. Születésnapjára [Festschrift for Zoltán Kodály's 70th birthday], ed. by B. Szabolcsi and D. Bartha, Budapest: Akadémiai Kiadó, pp. 169-98.

1954: Széki Gyüjtés [Szék collection], Budapest: Zenemükiadó.

1955: Körispataki Gyüjtés [Körispatak collection], Budapest: Zenemükiadó.

MARTIN, GYÖRGY, ed.

1980: Magyar Néptánchagyományok [Hungarian folk dance traditions], ed. by B. Andrásfalvy, J. Borbély, A. Lányi, E. Pesovar, \& F. Pesovar, Budapest: Zenemükiadó, pp. 11-15.

NAPOCENSIS, ANONYMUS.

1979: "Methods of Rumanization employed in Transylvania", in Witnesses to Cultural Genocide, ed. by G. Schöpflin, New York: American Transylvanian Federation and Committee for Human Rights in Rumania, pp. 57-87.

PAPP-ZUBRITS, SUSAN M.

1983: "Reflections of the members of three waves of Hungarian immigrants in Ontario," in Roots and Realities among Eastern and Central Europeans, ed. by Martin L. Kovács, Edmonton: Central and East European Studies Association of Canada, pp. 155-64.

RICE, TIMOTHY.

1987: "Toward the Remodelling of Ethnomusicology", in Ethnomusicology 31(3): 469-88.

\section{SÁROSI, BÁLINT.}

1978: Gypsy Music, Budapest: Corvina.

1980: "Hungary: folk music" in New Grove's Dictionary of Music, London: Macmillan, Vol. VIII, pp. 807-808. 
SZÁSZ, JÁNOS.

1981: "Beszélgetés Martin Györggyel az új folklórhullám és néptáncmozgalom elözményeiröl" [Conversation with György Martin concerning the sources of the new folklore and folk dance momement] in Kultúra és Közösség [Culture and community], (Budapest), 4: 42-53.

\section{VERDERY, KATHERINE.}

1983: Translyvanian Villagers, Berkeley: University of California Press.

VERESS, BULCSÚ.

1983: "The status of minority rights in Transylvania; international legal expectations and Rumanian realities," in Transylvania: the Roots of Ethnic Conflict, ed. by J. F. Caldow et al., Kent,Ohio: Kent State University Press, pp. 269-88.

\section{ZADUBÁN, GEORGE.}

1983: "Hungary" in Encyclopedia of Music in Canada, ed. by H. Kallmann et al., Toronto: University of Toronto Press, p. 439. 